\title{
KNOWLEDGE AND IMPLEMENTATION OF OUTCOME-BASED EDUCATION IN THE MATHEMATICS DEPARTMENT OF MAPUA UNIVERSITY
}

\author{
John Christoper Glino Carlos ${ }^{1}$ (1) and John Paolo Eriche Guingab Dacoco ${ }^{1}$ (1) \\ ${ }^{1}$ Department of Mathematics, Mapua University, Manila, Philippines
}
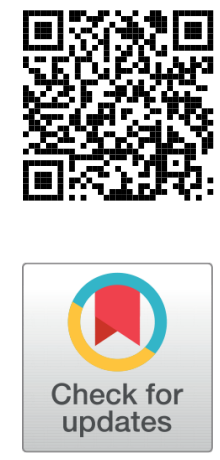

Received 3 April 2021

Accepted 14 April 2021

Published 30 April 2021

Corresponding Author John Christoper Glino Carlos, jcgca rlos95@gmail.com

DOI 10.29121/

granthaalayah.v9.i4.2021.3854

Funding: This research received no specific grant from any funding agency in the public, commercial, or not-for-profit sectors.

Copyright: (C) 2021 The Author(s). This is an open access article distributed under the terms of the Creative Commons Attribution License, which permits unrestricted use, distribution, and reproduction in any medium, provided the original author and source are credited.

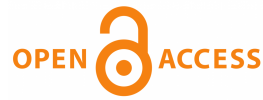

\section{ABSTRACT}

An increasing global demand for competitive graduates set off different universities around the world to shift their educational approach to Outcome-Based Education (OBE). Assessment on the status of the implementation of OutcomeBased Education is beneficial to various sectors of the educational body by using the results as their benchmark in maximizing the effectiveness of the system to their learners. The purpose of the study is to assess the level of implementation of OBE and its association with the scholastic characteristics of the students. The study is a descriptive research that involved the faculty and students of the mathematics department of Mapua university. The results showed that the respondents have a very high level of knowledge and high level of practice on the implementation of OBE. Results also showed that the level of implementation of OBE is associated with the scholastic characteristics of the students. It is then recommended that teachers would continue implementing OBE in mathematics courses as it has great impact on the behavior and performance of the students. In this context the department should come up with a monitoring program so that the effective implementation of OBE is ensured.

Keywords: Outcome-Based Education, Scholastic Characteristic

\section{INTRODUCTION}

The demand for standardized education and globally competitive Filipinos mobilized the shift from Objective-Learning Education to Outcome-Based Education (henceforth OBE) as the main framework in enhancing the quality of Higher Education in the Philippines. In a speech during the lecture of Dr. William Spady about OBE in 2015, Dr. Reynaldo B. Vea, president of Mapúa, clarified that "OBE's very spirit is to constantly raise the level of achievement of student performance". This approach to learning ensures that the students will be producing outcomes that showcase their learning in a specific field and will produce graduates who know how to adapt 
and think critically in solving increasingly complex and difficult challenges of today's environment.

In comparison with the traditional approach, wherein the focus is on the input and the completion of objectives, OBE focuses on student's output and their active role in studying the given material and managing their learning to effectively meet the necessary outcome for a specific course. This paved the way for educators to have a different view in the learning process and the assessment methods. With the implementation of OBE, assessment methods started to become diverse and new learning disciplines are introduced to obtain the outcomes.

Tucker (2004) emphasized that OBE is a process that involves the restructuring of curriculum, assessing and reporting practices in education. Therefore, the success of OBE's implementation depends on educator's understanding and the proficient practice of OBE. Without proper documentation on the level of their understanding and practice of OBE it will

be difficult to learn the opportunities to improve the system to meet the needs of different schools and universities that are planning to adopt OBE.

The OBE system has been formally implemented in Mapua University in SY 20062007. Although the system has been adapted by the University for a long time, there has been no clear documentation on the understanding of OBE for both students and teachers, its implementation as well as its effectiveness in as far as the course outcomes are concerned. The sustained generation of data about the implementation and effectiveness of $\mathrm{OBE}$ is essential in the continuous improvement of the learning process.

This study will focus on the assessment of the knowledge and implementation of OBE in the Mathematics Department of Mapua University. In particular, the study aims to answer three specific objectives. First, the study aims to determine the level of implementation of OBE as measured in terms of knowledge and practice as assessed by the data from faculty members and students. The second objective is to determine the scholastic characteristic of students who are exposed to the OBE system. Lastly, the study will investigate the effects of the implementation of OBE in the scholastic characteristic of students.

The result of this study will be beneficial to the different members of the school community namely the head of the Mathematics Department, stakeholders, and the Curriculum Developers. The findings will be a good source of input for the head of the Mathematics Department for future planning and faculty development. The data that will be gathered by this study will be available to use by the stakeholders of the University as a factor in making important decisions related to governance, operation, or improvement of the school. The Curriculum Developers of Mapua University will benefit from this study by using the results of this study in improving the curriculum, driving the effectiveness of OBE to the students' scholastic characteristics.

This study aims to measure the level of knowledge and implementation of OBE in the Mathematics Department of Mapua University and establish its effect on the stu- 
dents' scholastic characteristics. The data will be gathered from the professors of the Mathematics Department and their respective college students at Mapua University, Intramuros, Manila. This study is only limited to the Mathematics Department and does not include other departments.

\subsection{EFFECTIVENESS OF OBE}

In the late 90's James Coleman was tasked by the Commissioner of Education of the American government to conduct a research to figure out if the public schools are receiving equal funding and if education is provided fairly, regardless of the person's family and socioeconomic background. Coleman's research found out that the funding for the public schools is given fairly but there is segregation between white and people of color. Surprisingly, the data on his research reveal that physical amenities is not a big factor affecting a student's educational success, it is the socioeconomic background of the student playing the big role Cruickshank (1986).

The research of Coleman opened the mind of public figures, researchers, and critics that the current educational system is flawed and can still be improved. They believed that regardless of a student's socioeconomic background students can still learn and achieve success under proper guidance. This inspired the study and research about different educational systems.

The OBE system is focused on the constructivist method wherein the learners are responsible for constructing their own way of how they will get information and how they process that information to make meaning out of it while being facilitated by the teacher. This is different from the traditional approach wherein the learners are only passively receiving information Spady (1993).

In this type of educational system, students can be creative in how they want to learn. They are free to use materials that catch their interest. Students can read books, watch YouTube videos, research, etc., this type of system makes learning entertaining and fun. It keeps the students engage from the topic that they are studying.

The research of Guzman et al. (2017) revealed that there is a significant relationship between the knowledge and implementation of OBE. This means that the greater extent of knowledge of the faculty members, the higher chance they can achieve the objectives of OBE through practice. Nakkeeran et al. (2018) stated that the benefits of achieving the objectives of OBE are the following: a.) more direct and coherent curriculum, b.) graduates will be more relevant and competitive in the global workforce and c.) quality improvement will be continuous. Realizing the objectives of OBE is key to the effectiveness of the system.

An (2014) observed that OBE greatly helped the students improve both their scholastic behavior and performance. During class hours students are listening attentively to the instructor, they are also participating in the lesson and demonstrating critical thinking. After class hours, the students believed that they could make practical use of what they have learned, they think that they can express their 
ideas and achieve better outcomes. An (2014) therefore concluded that OBE can be adopted by schools as a new educational system and is beneficial to students regardless of age and gender.

\subsection{IMPLEMENTATION OF OBE}

Guzman et al. (2017) described that the extent of knowledge and practice of OBE shares a positively strong relationship. This means that the faculty members that possess a great extent of knowledge in OBE will most likely translate this knowledge into practice. Laguador and Dotong (2014) agreed that knowledge and practice of OBE shares a significant relationship, however, it is pointed out that in the case of their faculty members, the respondents indicated

average level of mastery in the proper assessment to be used. While in the case of an Asian university, An (2014) observed that OBE is being applied in terms of practice and learning environment

In order to maximize the potential of the new learning system An (2014) suggested the following: a.) Understand the essence and practicality of OBE, b.) Participation of faculty members, students, and academic personnel is necessary and, c.) Use different models of OBE assessment. While Cabaces et al. (2014) suggested that educators need to explore modern and diversified ways of teaching.

To enhance the standard of education in the Philippines, the Commission of Higher Education of the Philippines released a series of memorandum mandating college universities to improve their curriculum to meet the global standards. Zakaria and Yusoff (2011) pointed out that advancement of the current educational system is necessary in order to answer the demands of the increasing standards of global education. Cabaces et al. (2014) noted that academic institutions should extend their goals and educate their students with skills, attitudes, and behavior that they can use throughout their life rather than teaching them what can only be applied for the present work environment.

According to Custodio (2017), OBE guides the faculty members to align the curriculum, assessments, teaching methods and modules with the predetermined student outcomes. Outcomes in OBE come in different structures but Spady (1993) emphasizes that the most important structure should be the one that helps students achieve lifelong learning wherein what they learn in the classroom can be applied to everyday life. Morcke et al. (n.d.) agreed that the main focus of OBE is producing students that are ready to apply the skills and knowledge they acquired in school rather than students that are highly informed but struggles in translating it to application.

\subsection{BURDENS OF OBE}

Although OBE is seen as the educational reform that will bring forth the necessary advancements in the defining qualities of the graduates of the 20th century not everyone readily accepted it. There are critics and skeptics that voiced out their concerns regarding the shift of educational institutions to OBE. The researchers have compiled 
the burdens of OBE below.

In terms of technicality: OBE has no definite guidelines on what assessment, teaching method and strategy to use as described by An (2014). Young and Allais (2011) commented that OBE can be interpreted in different ways and follow varied sets of standards making it difficult in general use. Outcomes tend to be oversimplified making the process of learning limited as pointed out by Tam (2014). Sin (2014) said that the students cannot fully appreciate the learning outcomes yet since it presents little purpose to their current state in life.

In terms of resources: OBE demands a substantial amount of effort from the faculty members, curriculum developers, and other academic personnel to effectively implement OBE. Hassan (2012) explained that learning the objectives, methods of application and proper assessment of OBE is required before an academic institution adapts OBE as its' new educational system. Guico and Dolor (2013) observed that teachers voiced out concerns about the additional time OBE is taking from them to ensure that the quality of activities, exams and their teaching method is on par with the number of students that they are handling. The agreement of faculty members using OBE, the commitment of their time in studying OBE and their educational belief that OBE is effective are the main challenges in the implementation of OBE as concluded by An (2014).

\section{MATERIALS AND METHODS}

\subsection{RESEARCH DESIGN}

In the study, a descriptive method of research was used to collect data using a research survey questionnaire where quantitative analysis would be used to assess the degree of OBE implementation and analyze the scholastic characteristics of OBE student.

\subsection{RESPONDENTS OF THE STUDY}

The target respondents of the study are the faculty members of the Mathematics Department of Mapua University and students of Mapua University taking Mathematics subjects.

The population of the faculty members of the Mathematics Department is 22 . There are 20 Mathematics subjects offered during the 3rd Quarter of SY 2019-2020 with 84 unique sections and class size of 30 . Therefore, the population size of the Mathematics students is computed by multiplying the unique number of sections with the class size resulting in 2,520.

The researchers used the Slovin's formula for finding the lower bound of the sample size. The formula for this is given as, $n=\frac{N}{\left(1+N e^{2}\right)} x$ where $\mathrm{N}$ is the size of the population and e is the error margin. Using e $=0.05$ and $\mathrm{N}=2,520$ for the students enrolled in Mathematics subjects, we obtain a sample size of $n=345$. 
The researchers divided the estimated response rate to the computed sample size to determine how many survey questionnaires are needed to be handed out. Estimating the response rate to be $100 \%$ for the faculty members and $80 \%$ for the students and the computed sample size for the faculty members is 21 and 345 for the students. It is deemed that the number of survey questionnaires to be handed out to the faculty members is 21 and 431 to the students.

\subsection{INSTRUMENT}

A researcher-made survey questionnaire will be used as an instrument to gather data regarding the variables stated in the study. The instrument was subjected to content validity and approval to determine the relevance of the questions in achieving the objectives of the study.

\subsection{DATA GATHERING PROCEDURE}

The researchers administered the survey questionnaire personally to the members of the Mathematics Faculty Department and their students.

\subsection{DATA ANALYSIS}

Descriptive statistics such as median and composite median were used to measure the level of implementation of OBE and interpret the scholastic characteristics of students under OBE.

The Mann-Whitey U-Test will be used to assess if the opinion of teachers and students about OBE is substantially different. H_0 is set to be the perception of the teachers regarding OBE is the same as that of the students while the $\alpha=0.05$.

A Chi-square independence test was used to assess if there is a correlation between the degree of OBE implementation and the academic characteristics of the students.

To evaluate and interpret the collected data from the questionnaire, a 5-point Likert scale was used.

This guide was used to translate the following range of median verbally.

\begin{tabular}{|cc|} 
Range & Verbal Interpretation \\
\hline 5 & Very High \\
\hline 4 & High \\
\hline 3 & Neutral \\
\hline 2 & Low \\
1 & Very Low \\
\hline
\end{tabular}

\section{RESULTS AND DISCUSSIONS}

This part of the research returns the different results of the analyses that was conducted to answer the objectives of this research. The measure of the level of imple- 
mentation of $\mathrm{OBE}$, the difference between the perception of the faculty and the students regarding $\mathrm{OBE}$, and the association of the level of implementation with the scholastic characteristics of the students is discussed here. As well as the implication of the results to the Mathematics Department of Mapua University.

\begin{tabular}{|c|c|c|c|}
\hline S.N. & Statements & Median & VI \\
\hline 1. & $\begin{array}{l}\text { I know how to identify the } \\
\text { outcomes the learners need to } \\
\text { achieve. }\end{array}$ & 5 & Very High \\
\hline 2. & $\begin{array}{l}\text { I know how to utilize OBE in } \\
\text { developing Major exams and } \\
\text { Projects. }\end{array}$ & 5 & Very High \\
\hline 3. & $\begin{array}{l}\text { I know how to use OBE in } \\
\text { delivering my Instructions for my } \\
\text { students to develop a higher order } \\
\text { of thinking. }\end{array}$ & 5 & Very High \\
\hline 4. & $\begin{array}{l}\text { I am Knowledgeable about the } \\
\text { formulation of the faculty } \\
\text { department's PEOs. }\end{array}$ & 5 & Very High \\
\hline 5. & $\begin{array}{l}\text { I am knowledgeable about the } \\
\text { mission and vision of the faculty } \\
\text { department. }\end{array}$ & 5 & Very High \\
\hline 6. & $\begin{array}{l}\text { I am knowledgeable about the } \\
\text { facilitation of OBE in the } \\
\text { classroom. }\end{array}$ & 4 & High \\
\hline 7. & $\begin{array}{l}\text { I know how to adapt a student - } \\
\text { centered approach in teaching my } \\
\text { lessons. }\end{array}$ & 4 & High \\
\hline 8. & $\begin{array}{l}\text { I know how to create a healthy } \\
\text { and interactive environment of } \\
\text { learning in my classroom. }\end{array}$ & 4 & High \\
\hline 9. & $\begin{array}{l}\text { I am knowledgeable about } \\
\text { assessing the CLOs using different } \\
\text { assessment techniques. }\end{array}$ & 4 & High \\
\hline 10. & $\begin{array}{l}\text { I am knowledgeable about } \\
\text { curriculum alignment and } \\
\text { mapping. }\end{array}$ & 4 & High \\
\hline
\end{tabular}

Table 1 onsists of a computed median together with its verbal interpretation of the level of OBE implementation by the faculty members through knowledge.

The mathematics faculty members possess a very high level of knowledge in the implementation of OBE in terms of identifying the learning outcomes the students' need to achieve and the formulation of the faculty department's PEOs. It is denoted by its corresponding median of 5 .

The respondents are also shown to be having a very high level of knowledge with the mission and vision of the faculty department, how to use OBE in the delivery of lessons for the learners to develop higher order of thinking and how to utilize OBE in developing major exams and projects. This is indicated by their median of 5 . 
Assessing the CLOs using different assessment techniques and facilitation of OBE in the classroom has a median of 4 . This indicates that respondents have a high level of understanding on both items.

Knowledge about curriculum alignment and mapping, adapting to a studentcentered approach and creating a healthy and interactive environment of learning have a median of 4 with the verbal interpretation of high.

The results suggest that the faculty members have a very high level of knowledge in the different techniques, methods, and discipline in the implementation of OBE.

Table 2 Level of practice in OBE implementation by faculty

\begin{tabular}{|c|c|c|c|}
\hline S.N. & Statements & Median & VI \\
\hline 1. & $\begin{array}{l}\text { I sequence the activities across the course } \\
\text { appropriately. }\end{array}$ & 5 & Very High \\
\hline 2. & $\begin{array}{l}\text { I keep records about the OBE assessment } \\
\text { of my students. }\end{array}$ & 5 & Very High \\
\hline 3. & $\begin{array}{l}\text { I ensure that the learners clearly } \\
\text { understand what outcomes are expected } \\
\text { from them at the end of the course. }\end{array}$ & 5 & Very High \\
\hline 4. & $\begin{array}{l}\text { I ensure that the teaching and learning } \\
\text { activities are appropriate to the course. }\end{array}$ & 4 & High \\
\hline 5. & $\begin{array}{l}\text { I require my students to keep their exams } \\
\text { and activities in a portfolio for analysis. }\end{array}$ & 4 & High \\
\hline 6. & $\begin{array}{l}\text { I provide my students corrective actions } \\
\text { for learning such as advising and remedial. }\end{array}$ & 4 & High \\
\hline 7. & $\begin{array}{l}\text { I keep documents of using different } \\
\text { techniques for the assessment of CLOs } \\
\text { following the OBE template. }\end{array}$ & 4 & High \\
\hline 8. & $\begin{array}{l}\text { I use a student- centered approach in } \\
\text { delivering my instructions. }\end{array}$ & & \\
\hline 9. & $\begin{array}{c}\text { I give my students opportunities to work } \\
\text { as a group to develop collaborative } \\
\text { learning. }\end{array}$ & 4 & High \\
\hline 10. & $\begin{array}{l}\text { I equally encourage individual learning in } \\
\text { my instruction. }\end{array}$ & 4 & High \\
\hline
\end{tabular}

Table 2 consists of a computed median together with its verbal interpretation of the level of OBE implementation by the faculty members through practice.

Sequencing of activities across the course appropriately has a median of 5 while accurately discussing the expected outcomes to the learners which has a median of 4.

The respondents demonstrated a very high level of practice in keeping records about OBE assessment of their students and a high level of practice in giving opportunities for students to work as a group to develop collaborative learning, participating in seminars and discussions about OBE and ensuring that the teaching and learning activities were appropriate for the course. The corresponding median for the said practice is 5, 4, 4 and 4 respectively. 
Discussing the criteria for assessment to the students which has a median of 4 , in verbal interpretation means high level of practice. Providing the students advising and remedial as a form of corrective action is highly practiced. Use of different techniques for the assessments of CLOs is also highly practiced. Both have a median of 4.

Employing a portfolio analysis for the students to keep their exams and activities is highly practiced and has a median of 4 . With a median of 4 , a student-centered approach in delivering instructions has a high level of practice by the respondents. Also, individual learning is being highly encouraged indicated by the median of 4 .

Practical application of skills such as practicum, interview, and application as part of the learner's activities has a median of 4 and is still being highly practiced among the respondents.

It is observed that the faculty members highly practice the techniques, methods, and discipline in implementing OBE as their approach in teaching.

Table 3 Perception of Students on the Implementation of OBE (Knowledge)

\begin{tabular}{|c|c|c|c|}
\hline S.N. & Statements & Median & VI \\
\hline 1. & $\begin{array}{l}\text { The professor knows how to identify the outcomes } \\
\text { the learners need to achieve. }\end{array}$ & 4 & High \\
\hline 2. & $\begin{array}{c}\text { The professor knows how to adapt a } \\
\text { student-centered approach in teaching his/her } \\
\text { lessons. }\end{array}$ & 4 & High \\
\hline 3. & $\begin{array}{c}\text { The professor knows how to create a healthy and } \\
\text { interactive environment of learning in his/her } \\
\text { classroom }\end{array}$ & 4 & High \\
\hline 4. & $\begin{array}{l}\text { The professor knows how to utilize OBE in } \\
\text { developing Major Exams, Activities and Projects. }\end{array}$ & 4 & High \\
\hline 5. & $\begin{array}{c}\text { The professor knows how to use OBE in delivering } \\
\text { his/her instructions for us learners to develop a } \\
\text { higher order of thinking. }\end{array}$ & 4 & High \\
\hline 6. & $\begin{array}{l}\text { The professor is knowledgeable about the } \\
\text { formulation of the faculty department's Program } \\
\text { Educational Objectives (PEOs). }\end{array}$ & 4 & High \\
\hline 7. & $\begin{array}{l}\text { I keep documents of using different techniques for } \\
\text { the assessment of CLOs following the OBE } \\
\text { template. }\end{array}$ & 4 & High \\
\hline 8. & $\begin{array}{l}\text { The professor is knowledgeable about the mission } \\
\text { and vision of the faculty department. }\end{array}$ & & \\
\hline 9. & $\begin{array}{c}\text { The professor is knowledgeable about assessing } \\
\text { the Course Learning Outcomes (CLOs) using } \\
\text { different assessment techniques. }\end{array}$ & 4 & High \\
\hline 10. & $\begin{array}{c}\text { The professor is knowledgeable about curriculum } \\
\text { alignment and mapping. }\end{array}$ & 4 & High \\
\hline
\end{tabular}

Table 3 is about the measure of the level of implementation of OBE through the perception of the students. Every statement in this section of the survey received a median of 4 which means that in the eyes of the students there is a high level of implementation of OBE in terms of knowledge. 
Table 4 Perception of Students on the Implementation of OBE (Practice)

\begin{tabular}{|c|c|c|c|}
\hline S.N. & Statements & Median & VI \\
\hline 1. & $\begin{array}{c}\text { The professor provides us learners corrective } \\
\text { actions for learning such as advising and } \\
\text { remedial. }\end{array}$ & 4 & High \\
\hline 2. & $\begin{array}{l}\text { The professor sequences the activities across } \\
\text { the course appropriately. }\end{array}$ & 4 & High \\
\hline 3. & $\begin{array}{l}\text { The professor has discussed the criteria for } \\
\text { assessment to the students for us to } \\
\text { understand how we are being assessed. }\end{array}$ & 4 & High \\
\hline 4. & $\begin{array}{l}\text { The professor has discussed the criteria for } \\
\text { assessment to the students for us to } \\
\text { understand how we are being. assessed }\end{array}$ & 4 & High \\
\hline 5. & $\begin{array}{l}\text { The professor requires us students to keep Our } \\
\text { exams and activities in a portfolio for analysis. }\end{array}$ & 4 & High \\
\hline 6. & $\begin{array}{l}\text { The professor ensures that us learners clearly } \\
\text { understand what outcomes are expected from } \\
\text { us at the end of the course. }\end{array}$ & 4 & High \\
\hline 7. & $\begin{array}{l}\text { The professor uses a student-centered } \\
\text { approach in delivering his/her instructions. }\end{array}$ & 4 & High \\
\hline 8. & $\begin{array}{l}\text { The professor gives his/her students } \\
\text { opportunities to work as a group to develop } \\
\text { collaborative learning. }\end{array}$ & & \\
\hline 9. & $\begin{array}{l}\text { The professor equally encourages individual } \\
\text { learning on his/her instructions. }\end{array}$ & 4 & High \\
\hline 10. & $\begin{array}{l}\text { The professor employs practical application of } \\
\text { skills such as (practicum, interview, and } \\
\text { application) as a part of Our activity. }\end{array}$ & 4 & High \\
\hline
\end{tabular}

Table 4 measures the perception of the students in the implementation of OBE through practice, which also obtained a median of 4 . This means that aside from the students perceiving the implementation of OBE in the classroom in terms of knowledge to be high, this also translates to a high level of implementation of OBE through practice.

Table 5 shows the level of scholastic characteristics of the students who are exposed to the OBE system in terms of behavior.

One impact of OBE to the students who are exposed to it is being responsible with their own learning. It has a median of 4 . The verbal interpretation is high.

Increase in speed and accuracy in accomplishing tasks, becoming an active listener, developing good study habits, and becoming cooperative in discussions all belong to the high-level category of good behavior possessed by the students under the exposure of the students in the OBE system. The following behavior has a median of 4 .

Following the high-level category are development of focus, confidence with their skills, being more competitive and becoming a critical thinker. With all having a median of 4 . 
Table 5 Scholastic Characteristics of the Students Who Are Exposed to the OBE System (Behavior)

\begin{tabular}{rccc}
\hline S.N. & Statements & Median & VI \\
\hline 1. & Become an active listener. & 4 & High \\
\hline 2. & $\begin{array}{c}\text { Become cooperative in } \\
\text { discussions. }\end{array}$ & 4 & High \\
\hline 3. & $\begin{array}{c}\text { Increase my speed and accuracy } \\
\text { in accomplishing my tasks. }\end{array}$ & 4 & High \\
\hline 4. & Be outspoken with my ideas. & 4 & High \\
\hline 5. & Become a critical thinker. & 4 & High \\
\hline 6. & Develop my focus. & 4 & High \\
\hline 7. & Be responsible for my learning. & 4 & High \\
\hline 8. & Be confident with my skills. & 4 & High \\
\hline 9. & Be more competitive. & 4 & High \\
\hline 10. & Develop my study habits. & 4 & \\
\hline
\end{tabular}

It is observed that students under the OBE system possess higher order thinking skills. With the implementation of OBE, the professors can maximize the good effects of it on the scholastic behavior and performance of the students. It can deal with the issue that was observed in the study of Patena and Dinglasan (2013) wherein Filipino students excel in knowledge acquisition but fare poorly with problems requiring critical thinking.

Another behavior observed on high level of category is being outspoken with their ideas. It also received a median 4.

The resulting behaviors has high as a remark for the scholastic characteristics of the students in terms of their behavior in an OBE modeled classroom. The students showed a set of behavior beneficial to their learning.

Table 6 Scholastic Characteristics of the Students Who Are Exposed to the OBE System (Performance)

\begin{tabular}{cccc}
\hline S.N. & Statements & Median & VI \\
\hline 1. & Translate my thoughts into sensible & 4 & High \\
writing. & Achieve better outcomes for my course. & 4 & High \\
\hline 2. & Share my ideas spontaneously through \\
speaking. & 4 & High \\
\hline . & Receive higher grades. & 4 & High \\
\hline 5. & $\begin{array}{c}\text { Collaborate with my classmates in } \\
\text { accomplishing difficult tasks. } \\
\text { Apply what I have learned. }\end{array}$ & 4 & High \\
\hline 6. & High
\end{tabular}

The data on Table 6 illustrate the level of scholastic characteristics of the students who are exposed to the OBE system through performance.

Application of their learning obtained high in terms of performance. It has a median of 4 . 
Collaboration with their classmates in accomplishing difficult tasks, translating their thoughts into sensible writing, achieving better outcomes for their course, and sharing their ideas through speaking share a common category which is high level of performance. Their respective median is 4,4 and 4 .

Receiving higher grades also received a median of 4 .

The result shows that the students have a high level of performance under the OBE system. It is manifested by their median of 4 which has a verbal interpretation of high performance.

\begin{tabular}{lcccc}
\hline $\begin{array}{l}\text { Table } 7 \\
\text { OBE }\end{array}$ & Difference in the perception about knowledge on \\
\hline Group & Median & U- statistic & p-value & Significance \\
\hline Faculty & 5 & 976.23 & 0.0012 & Highly Significant \\
Student & 4 & & & \\
\hline
\end{tabular}

In line with the researcher's objective to determine if there is a statistical difference between the perception of the professor (knowledge) and the perception of the students (knowledge) on the implementation of OBE, a two-tailed t-test for mean has been used There is a highly significant statistical difference, as shown in Table 7 , between the perception of the faculty and the students' perception of OBE knowledge.

\begin{tabular}{|c|c|c|c|c|}
\hline Group & Median & U- statistic & $\mathrm{p}$-value & Significance \\
\hline Faculty & 4 & 976.23 & 0.0412 & Significant \\
\hline Student & 4 & & & \\
\hline
\end{tabular}

The same test has been used in Table 8 to identify if there is a significant difference between the perception of the professor (practice) and the perception of students (practice) on the implementation of OBE. The analysis that there is a major difference between the subjects being tested.

A chi-square test was performed to examine the relation between the level of OBE implementation of professor (knowledge) and the scholastic characteristics of students (behavior) shown in Table 9 .

The relation between these variables was significant, $X^{2}(1, \mathrm{~N}=357)=5.0463, \mathrm{p}$ $=0.0247$.

Therefore, there is an association between the level of OBE implementation of professor (knowledge) and the scholastic characteristics of students (behavior)

Table 10 display the result for the chi-square test between the level of implementation of OBE by the faculty members (knowledge) and the scholastic characteristics of students (performance) 
Table 9 Association between the level of implementation of OBE by the faculty, as perceived by students, with their scholastic characteristics.

\begin{tabular}{cccc}
\hline & \multicolumn{2}{c}{ Scholastic Characteristic } & \\
\hline $\begin{array}{c}\text { Observed Level of } \\
\text { Implementation }\end{array}$ & High & Low & Total \\
\hline High & 186 & 87 & 273 \\
Low & 46 & 38 & 84 \\
Total & 232 & 125 & 357 \\
\hline Expected Level of & Scholastic Characteristic & Total \\
Implementation & High & Low & 273 \\
High & 177.4 & 95.59 & 84 \\
\hline Low & 54.59 & 29.41 & 357 \\
Total & 232 & 125 & \\
\hline
\end{tabular}

chi-square $=5.0463 ;$ p-value $=0.0247$ (significant $)$

Table 10 Association between the level of implementation of OBE by the faculty, as perceived by students, with their scholastic characteristics.

\begin{tabular}{|cccc|}
\hline \multicolumn{2}{c}{ Scholastic Characteristic } & \\
\hline Observed Level of Implementation & High & Low & Total \\
\hline High & 193 & 77 & 270 \\
\hline Low & 62 & 44 & 106 \\
Total & 255 & 121 & 376 \\
\hline & Scholastic Characteristic & \\
\hline Expected Level of Implementation & High & Low & Total \\
\hline High & 183.11 & 86.59 & 270 \\
\hline Low & 74.89 & 34.11 & 106 \\
\hline Total & 255 & 121 & 376 \\
\hline
\end{tabular}

chi-square $=5.8859 ;$ p-value $=0.0153$ (significant $)$

The computed chi-square score is $X^{2}(1, \mathrm{~N}=376)=5.8859, \mathrm{p}=0.0153$.

The proportion of the professors' extent of implementation of OBE (knowledge) did not differ from the performance of the students exposed to the OBE system.

As for Table 11 it presents the calculation for the p-value of the OBE implementation of professors and the scholastic behavior of students under OBE.

The calculated p-value is 0.0010 , this is less than the significance level of 0.05 . Therefore, it means that the level of OBE implementation of the professors (practice) has statistically significant value to the scholastic behavior of the students under OBE.

Table 12 is all about testing the null hypothesis that the level of practice of OBE implementation by the faculty members has no significant relationship with the performance of the students under OBE.

According to the results of having a p-value being less than the significant level of 0.05 . The decision that the researchers came up with the null hypothesis must be dismissed and the alternative hypothesis accepted, which is that there is a substantial 
Table 11 Association between the level of implementation of OBE by the faculty, as perceived by students, with their scholastic characteristics.

\begin{tabular}{|c|c|c|c|}
\hline \multicolumn{4}{|c|}{ Scholastic Characteristic } \\
\hline Observed Level of Implementation & High & Low & Total \\
\hline High & 192 & 78 & 270 \\
\hline Low & 66 & 56 & 122 \\
\hline Total & 258 & 134 & 392 \\
\hline \multicolumn{4}{|c|}{ Scholastic Characteristic } \\
\hline Expected Level of Implementation & High & Low & Total \\
\hline High & 177.70 & 92.30 & 270 \\
\hline Low & 80.30 & 41.70 & 122 \\
\hline Total & 258 & 134 & 392 \\
\hline
\end{tabular}

significance level $=0.05 ; \mathrm{p}$-value $=0.0010$ (significant $)$

Table 12 Association between the level of implementation of OBE by the faculty, as perceived by students, with their scholastic characteristics.

\begin{tabular}{|cccc}
\hline \multicolumn{3}{c}{ Scholastic Characteristic } & \\
\hline Observed Level of Implementation & High & Low & Total \\
\hline High & 193 & 86 & 270 \\
\hline Low & 55 & 42 & 97 \\
Total & 248 & 124 & 376 \\
\hline & Scholastic Characteristic & \\
\hline Expected Level of Implementation & High & Low & Total \\
\hline High & 184.02 & 94.98 & 279 \\
\hline Low & 63.98 & 33.02 & 97 \\
\hline Total & 248 & 128 & 376 \\
\hline
\end{tabular}

significance level $=0.05 ; \mathrm{p}$-value $=0.0255$ (significant $)$

relationship between the observed variables.

\section{CONCLUSIONS AND RECOMMENDATIONS}

The research study was conducted at Mapua University. The respondents were the faculty members of the mathematics department and their students. They were selected using random sampling. Descriptive type of statistics was used. The statistical tools used were median, t-test and chi-square test.

The faculty members of the mathematics department have varied level of knowledge and practice on the implementation of OBE which range from high to very high. The students highly agree that their professors are knowledgeable in the implementation of OBE and that it is being practiced in their learning environment. Therefore, the perception of the professor and the students on the implementation of OBE through knowledge and practice are align. 
The students who are exposed to the OBE system have high level of scholastic characteristics both in terms of behavior and performance, however there's a room for improvement for the students to be more outspoken with their ideas and turn their scholastic behavior and performance to receive better grades.

It was found out that there is a substantial relationship between the level of implementation of OBE and the scholastic characteristics of the students. The higher level of implementation of OBE will yield to better academic behavior and performance of the students. Therefore, despite the burdens of OBE to the mathematics professors the result of better implementation of OBE to the students is invaluable.

The faculty members of the mathematics department are highly encouraged to continue the implementation OBE system as it has great impact on the behavior and performance of students in the classroom. Since the effectiveness of OBE has been proven, the students are urged to enhance their knowledge about the system, to further adapt to the culture of OBE learning, as this will maximize the effect of OBE to their scholastic characteristics. It is recommended to the faculty members to attend training and seminars about OBE as it will boost their mastery on the implementation of OBE which in return will produce a highly functional OBE centered learning culture.

\section{ACKNOWLEDGEMENTS}

This work would not have been possible without the guidance of our professor and advisor Edgar M. Adina. Thank you for your patience, motivation and continuous support. We appreciate everything that you have taught us.

Special thanks to Dr. Mylen Aala-Capuno, Dean of the Faculty, for providing us with all the necessary permissions for the research.

\section{APPENDICES}

\subsection{APPENDIX A}

\section{Survey Questionnaire for Professors}

Knowledge and Implementation of Outcome-Based Education in the Mathematics Department of Mapua University

Professor (Optional):

This survey is conducted to assess your knowledge, practice, and behavior regarding the Implementation of Outcome-Based Education in the Mathematics Department of Mapua University. Please answer this survey question with utmost truthfulness and sincerity. Rest assured that all answers on this survey will be kept confidential and will be used only for the purposes of the study.

For each Statement on this table, check the appropriate box of your answer. 


\begin{tabular}{|c|c|c|c|c|c|c|}
\hline S.N. & $\begin{array}{l}\text { Level of OBE } \\
\text { Implementa- } \\
\text { tion by the } \\
\text { Faculty } \\
\text { Member } \\
\text { - Knowledge }\end{array}$ & $\begin{array}{c}1 \text { Very } \\
\text { Low }\end{array}$ & 2 Low & $\begin{array}{c}3 \\
\text { Moderate }\end{array}$ & 4 High & 5 Very High \\
\hline 1. & $\begin{array}{l}\text { I know how to } \\
\text { identify the } \\
\text { outcomes the } \\
\text { learners need to } \\
\text { achieve }\end{array}$ & & & & & \\
\hline 2. & $\begin{array}{l}\text { I know how } \\
\text { adapt student - } \\
\text { centered } \\
\text { approach in } \\
\text { teaching my } \\
\text { lessons }\end{array}$ & & & & & \\
\hline 3. & $\begin{array}{l}\text { I know how to } \\
\text { create a healthy } \\
\text { and interactive } \\
\text { environment of } \\
\text { learning in my } \\
\text { classroom }\end{array}$ & & & & & \\
\hline 4. & $\begin{array}{l}\text { I know how to } \\
\text { utilize OBE in } \\
\text { developing } \\
\text { Major exams } \\
\text { and Projects }\end{array}$ & & & & & \\
\hline 5. & $\begin{array}{l}\text { I know how to } \\
\text { use OBE in } \\
\text { delivering my } \\
\text { Instructions for } \\
\text { my students to } \\
\text { develop higher } \\
\text { order of } \\
\text { thinking }\end{array}$ & & & & & \\
\hline 6. & $\begin{array}{c}\text { I am } \\
\text { knowledgeable } \\
\text { about the } \\
\text { facilitation of } \\
\text { OBE in the } \\
\text { classroom }\end{array}$ & & & & & \\
\hline 7. & $\begin{array}{c}\text { I am } \\
\text { Knowledgeable } \\
\text { about the } \\
\text { formulation of } \\
\text { the faculty } \\
\text { department's } \\
\text { PEOs }\end{array}$ & & & & & \\
\hline
\end{tabular}




\begin{tabular}{cc}
\hline Table 13 continued \\
\hline $8 . \quad$ I am \\
knowledgeable \\
about the \\
mission and \\
vision of the \\
faculty \\
department \\
I am \\
knowledgeable \\
about assessing \\
the CLOs using \\
different \\
assessment \\
techniques \\
I am \\
knowledgeable \\
about \\
curriculum \\
alignment and \\
mapping \\
\hline
\end{tabular}

\section{S.N. \\ Level of OBE \\ 1 Very \\ 2 Low \\ 3 Moderate \\ 4 High \\ 5 Very \\ Implementation by the \\ Low \\ High \\ Faculty Member \\ - Practice}

1. I provide my students

corrective actions for

learning such as

advising and remedial

2. I sequence the activities

across the course

appropriately

3. I have discussed the

criteria for assessment

to my students for them

to understand how they are being assessed

4. I ensure that the teaching and learning

activities were

appropriate to the

course

5. I require my students to

keep their exams and

activities in a portfolio

for analysis

Continued on next page 


\section{Table 14 continued}

6. I keep records about the

OBE assessment of my students

\begin{tabular}{|c|c|}
\hline 7. & $\begin{array}{l}\text { I keep documents of } \\
\text { using different } \\
\text { techniques for the } \\
\text { assessment of CLOs } \\
\text { following the OBE } \\
\text { template }\end{array}$ \\
\hline 8. & $\begin{array}{l}\text { I ensure that the } \\
\text { learners clearly } \\
\text { understand what } \\
\text { outcomes is expected } \\
\text { from them at the end of } \\
\text { the course }\end{array}$ \\
\hline 9. & $\begin{array}{l}\text { I use student- centered } \\
\text { approach in delivering } \\
\text { my instructions }\end{array}$ \\
\hline 10. & $\begin{array}{l}\text { I give my students } \\
\text { opportunities to work as } \\
\text { a group to develop } \\
\text { collaborative learning }\end{array}$ \\
\hline 11. & $\begin{array}{l}\text { I equally encourage } \\
\text { individual learning in } \\
\text { my instruction }\end{array}$ \\
\hline 12. & $\begin{array}{l}\text { I have participated in } \\
\text { seminars and } \\
\text { discussions about OBE } \\
\text { in the University }\end{array}$ \\
\hline 13. & $\begin{array}{c}\text { I employ practical } \\
\text { application of skills such } \\
\text { as (practicum, interview } \\
\text { and application) as a } \\
\text { part of their activity }\end{array}$ \\
\hline
\end{tabular}

\section{APPENDIX B}

\section{Survey Questionnaire for Students}

Knowledge and Implementation of Outcome-Based Education in the Mathematics Department of Mapua University

Name: Section/Course:

Professor:

This survey is conducted to assess your knowledge, practice, and behavior regarding the Implementation of Outcome-Based Education in the Mathematics Department of Mapua University. Please answer this survey question with utmost truthfulness and sincerity. Rest assured that all answers on this survey will be kept confidential and will be used only for the purposes of the study. 
Level of OBE Implementation by the Faculty Member

\begin{tabular}{|c|c|c|c|c|c|c|}
\hline S.N. & $\begin{array}{l}\text { Perception of Students } \\
\text { on the Implementation } \\
\text { of OBE } \\
\text { • Knowledge }\end{array}$ & $\begin{array}{c}1 \text { Very } \\
\text { Low }\end{array}$ & 2 Low & 3 Moderate & 4 High & $\begin{array}{c}5 \text { Very } \\
\text { High }\end{array}$ \\
\hline 1. & $\begin{array}{l}\text { The professor knows how } \\
\text { to identify the outcomes } \\
\text { the learners need to } \\
\text { achieve }\end{array}$ & & & & & \\
\hline
\end{tabular}

2. The professor knows how to adapt student-centered approach in teaching his/her lessons

3. The professor knows how
to create a healthy and
interactive environment of
learning in his/her
classroom

4. The professor knows how to utilize OBE in developing Major Exams, Activities and Projects

5. The professor knows how
to use OBE in delivering
his/her instructions for us
learners to develop higher
order of thinking
The professor is
knowledgeable about the
facilitation of OBE in the
classroom
The professor is
knowledgeable about the
formulation of the faculty
department's Program
Educational Objectives
(PEOs)
The professor is
knowledgeable about the
mission and vision of the
faculty department
The professor is
knowledgeable about
assessing the Course
Learning Outcomes
(CLOs) using different
assessment techniques

Continued on next page 


\begin{tabular}{l} 
Table 15 continued \\
\hline The professor is \\
knowledgeable about \\
curriculum alignment and \\
mapping \\
Perception of Students $\quad$ 1 Very $\quad$ 2 Low $\quad$ 3 Moderate $\quad$ 4 High $\quad$ 5 Very \\
on the Implementation \\
of OBE $\bullet$ Practice \\
The professor provides us \\
learners corrective actions \\
for learning such as \\
advising and remedial \\
The professor sequences \\
the activities across the \\
course appropriately \\
The professor has \\
discussed the criteria for \\
assessment to the \\
students for us to \\
understand how we are \\
being assessed \\
The professor has \\
discussed the criteria for \\
assessment to the \\
students for us to \\
understand how we are \\
being assessed
\end{tabular}

5. The professor requires us students to keep Our exams and activities in a portfolio for analysis

6. The professor ensures that us learners clearly understand what outcomes are expected from us at the end of the course

7. The professor uses student-centered approach in delivering his/her instructions

8. The professor gives his/her students opportunities to work as a group to develop collaborative learning

9. The professor equally encourages individual learning on his/her instructions 


\section{Table 15 continued}

10. The professor employs practical application of skills such as (practicum, interview and application) as a part of Our activity

\begin{tabular}{|c|c|c|c|c|c|c|}
\hline S.N. & $\begin{array}{c}\text { Scholastic Characteristics of } \\
\text { the Students Who Are Exposed } \\
\text { to the OBE System } \\
\text { - Behavior The Curriculum } \\
\text { Helped Me To: }\end{array}$ & $\begin{array}{l}1 \text { Very } \\
\text { Low }\end{array}$ & 2 Low & $\begin{array}{c}3 \\
\text { Moderate }\end{array}$ & 4 High & $\begin{array}{l}5 \text { Very } \\
\text { High }\end{array}$ \\
\hline 1. & Become an active listener & & & & & \\
\hline 2. & $\begin{array}{l}\text { Become cooperative in } \\
\text { discussions }\end{array}$ & & & & & \\
\hline 3. & $\begin{array}{l}\text { Increase my speed and accuracy } \\
\text { in accomplishing my tasks }\end{array}$ & & & & & \\
\hline 4. & Be outspoken with my ideas & & & & & \\
\hline 5. & Become a critical thinker & & & & & \\
\hline 6. & Develop my focus & & & & & \\
\hline 7. & Be responsible for my learning & & & & & \\
\hline 8. & Be confident with my skills & & & & & \\
\hline 9. & Be more competitive & & & & & \\
\hline 10. & Develop my study habits & & & & & \\
\hline
\end{tabular}

\begin{tabular}{|c|c|c|c|c|c|c|}
\hline S.N. & $\begin{array}{c}\text { Scholastic Characteristics } \\
\text { of the Students Who Are } \\
\text { Exposed to the OBE } \\
\text { System • Performance } \\
\text { The Curriculum Helped } \\
\text { Me To: }\end{array}$ & $\begin{array}{l}1 \text { Very } \\
\text { Low }\end{array}$ & 2 Low & 3 Moderate & 4 High & $\begin{array}{c}5 \text { Very } \\
\text { High }\end{array}$ \\
\hline 1. & $\begin{array}{c}\text { Translate my thoughts into } \\
\text { sensible writing }\end{array}$ & & & & & \\
\hline 2. & $\begin{array}{l}\text { Achieve better outcomes } \\
\text { for my course }\end{array}$ & & & & & \\
\hline 3. & $\begin{array}{c}\text { Share my ideas } \\
\text { spontaneously through } \\
\text { speaking }\end{array}$ & & & & & \\
\hline 4. & Receive higher grades & & & & & \\
\hline 5. & $\begin{array}{l}\text { Collaborate with my } \\
\text { classmates in } \\
\text { accomplishing difficult } \\
\text { tasks }\end{array}$ & & & & & \\
\hline 6. & Apply what I have learned & & & & & \\
\hline
\end{tabular}




\section{REFERENCES}

An, I. L. (2014). Impact of Outcome-Based Education Instruction to Accountancy Students in an Asian University. Asia Pacific Journal of Education, Arts and Sciences, 1(5), 48-52.

Cabaces, J., Blanco, A. J. S., Cabanas, J. E. A., Casapao, C. G., Guzman, J. P. D., Villa, M. A. C. D., \& Derla, R. V. R. (2014). Perception and Awareness of Nigerian Students towards Outcome-Based Education. International Journal of Academic Research in Progressive Education and Development, 3(1). Retrieved from https://dx.doi.org/10.6007/ijarped/ v3-i1/761 10.6007/ijarped/v3-i1/761

Cruickshank, D. R. (1986). A synopsis of effective school's research: Why it is done, how it is done, what are its findings, how they are implemented. Illinois School Research and Development, 22(3), 112-127.

Custodio, P. C. (2017).

Guico, T., \& Dolor, G. (2013). Level of Awareness and Possible Concerns of the Marine Faculty Members on Outcome-Based Education". Journal of International Academic Research for Multidisciplinary(7), 1-1.

Guzman, M. D., Edaño, D., \& Umayan, Z. (2017). Understanding the Essence of the OutcomesBased Education (OBE) and Knowledge of its Implementation in a Technological University in the Philippines. Asia Pacific Journal of Multidisciplinary Research, 5(4), 64-71.

Hassan, M. S. (2012). Challenges of implementing outcome-based engineering education in universities in Bangladesh. In 7th International Conference on Electrical and Computer Engineering (pp. 362-364).

Laguador, D. J. M., \& Dotong, D. C. I. (2014). Knowledge versus Practice on the OutcomesBased Education Implementation of the Engineering Faculty Members in LPU. International Journal of Academic Research in Progressive Education and Development, 3(1), 226-6348. Retrieved from https://dx.doi.org/10.6007/ijarped/v3-i1/640 10.6007/ ijarped/v3-i1/640

Morcke, A., Dornan, T., \& Eika, B. (n.d.). Retrieved from URL:www.iced2014.se/proceedings/ 1091_Morcke.pdf

Nakkeeran, R., Babu, R., Manimaran, R., \& Gnanasivam, P. (2018). Importance of Outcome Based Education (OBE) to Advance Educational Quality and enhance Global Mobility. International Journal of Pure and Applied Mathematics, 119, 1314-3395.

Patena, A. D. C., \& Dinglasan, B. (2013). Students Performance on Departmental Examination: Basis for Math Intervention Program. SSRN Electronic Journal, 1(14), 255-268. Retrieved from https://dx.doi.org/10.2139/ssrn.2276044 10.2139/ssrn.2276044

Sin, C. (2014). Lost in translation: the meaning of learning outcomes across national and institutional policy contexts. Studies in Higher Education(10), 39-39.

Spady, B. (1993). Retrieved from http://www.sntp.net/education/obe_explained.htm

Tam, M. (2014). Outcomes-based approach to quality assessment and curriculum improvement in higher education. Quality Assurance in Education, 22(2).

Tucker, B. (2004).

Young, M., \& Allais, S. (2011). The shift to outcomes-based frameworks. Key problems from a critical perspective. Austrian Open Access Journal of Adult Education, 14-14.

Zakaria, S., \& Yusoff, W. F. W. (2011). Teaching Management and Its Contribution StudentSatisfaction in Private Higher Institutions of Learning. International Journal of Trade, Economics and Finance, 387-390. Retrieved from https://dx.doi.org/10.7763/ijtef.2011 .v2.136 10.7763/ijtef.2011.v2.136 